\title{
Physicochemical and Microbiological Water Quality Assessment of Aba Waterside River, Aba, Nigeria
}

\author{
Bobor L.O. ${ }^{1, *}$ and Umeh C.M. ${ }^{1}$ \\ ${ }^{1}$ Department of Civil Engineering, Faculty of Engineering, University of Benin, Benin City, Nigeria \\ Corresponding Author: *lulu.akhigbe@ uniben.edu
}

\begin{abstract}
The indiscriminate disposal of industrial effluents and solid wastes in surface water bodies is detrimental to humans and aquatic organisms. Water quality monitoring is critical to identify pollutants of concern and develop effective management strategies. Hence, this study was conducted to assess the impact of waste disposal on the water quality of Aba Waterside River, Ogbor hill, Aba. Grab samples were collected upstream, midstream and downstream and some physicochemical and microbiological parameters were analyzed in accordance with standard methods for the analysis of water and wastewater. The results were compared with the Nigerian standard for drinking water quality and the national environmental effluent limitation regulations. Turbidity levels $(10-31 \mathrm{mg} / \mathrm{l})$ exceeded the maximum permissible levels for drinking water $(5 \mathrm{mg} / \mathrm{l})$ and may be associated with higher levels of embedded disease-causing microbes and potentially harmful organic and inorganic substances. The biological oxygen demand midstream (1960mg/l) was remarkably high due to the effluent discharged from the abattoirs at that point. Fecal coliforms $(3-198 M P N / 100 m l)$ were detected in all samples, indicating the presence of other potentially harmful microorganisms. The findings of this study indicate that the water is unsuitable for direct drinking water purposes and stringent water quality control measures should be implemented.
\end{abstract}

Keywords: Water Quality, Pollution, Aba Waterside River, Drinking Water, Effluents

\subsection{Introduction}

Surface water pollution and the consequent deterioration of aqueous systems is a major problem in developing and densely populated countries (Dahunsi et al., 2014; Ayandiran et al., 2018). Increased urban, industrial and agricultural activities and failure to enforce environmental laws have resulted in the indiscriminate disposal of large volumes of untreated wastewater and solid wastes in rivers and streams. These wastes contain harmful substances which are detrimental to human health, aquatic organisms and the ecosystem (Amadi, 2012; Tyagi et al., 2013; Dahunsi et al., 2014; Tchakonte et al., 2014; Onajoke et al., 2017; Ayadiran et al., 2018). Long term pollution alters the physical, chemical and biological nature of the receiving water bodies and affects the surrounding food web (Ewa et al., 2011; Amadi, 2012). According to Umalua et al. (2007), consumption of contaminated marine organisms capable of transmitting toxic elements or diseases to consumers is a major associated risk. Microbial pollutants cause waterborne and water-related diseases such as typhoid, cholera, bacillary dysentery, etc. (Ayadiran et al., 2018). The discharge of untreated sewage and industrial effluents with high nutrient loads into rivers also results in eutrophication (increased growth of aquatic plants and toxic algal blooms). This may cause depletion of dissolved oxygen leading to the death of aquatic animals (Morrison et al., 2001; Ewa et al., 2011; Ahwange et al., 2012).

Aba Waterside (Aba) river is a deep freshwater river in Aba, Abia State, Nigeria which is used for domestic, agricultural and industrial purposes. There are several industries, abbatoirs and laundry services and dumpsites located near the river. Due to poor waste management practices and nonenforcement of environmental laws, the river receives large volumes of untreated effluents and refuse (Nkwocha and Emeribe, 2005; Ubalua et al., 2007; Amadi, 2012; Atasie and Egbonu, 2017; Udo and 
Elendu, 2019). Some researchers have carried out studies investigating the extent of pollution in Aba Waterside/Aba River, with particular emphasis on heavy metal pollution and impact on aquatic organisms (Ubalua et al., 2007; Amadi, 2012; Atasie and Egbonu, 2017; Udo and Elendu, 2019). The heavy metal content of water, fish and shellfish in Aba River was evaluated in a study, with the metal concentrations exceeding allowable limits (Ubalua et al., 2007). Amadi (2012) investigated the impact of municipal and industrial wastes and agricultural runoff on Aba River by assessing the levels of heavy metal pollution. Atasie and Egbonu (2017) examined some water quality indicators and the impact of water samples from Aba Waterside River, Aba on the hematological indices of rats. In their study, water quality analysis was limited to biochemical oxygen demand, chemical oxygen demand, dissolved oxygen and total hardness. Udo and Elendu (2019) examined the public health implications of Aba river pollution.

The aim of this study was to assess the impact of indiscriminate waste disposal/anthropogenic activities on the water quality of Aba Waterside River, Ogbor hill, Aba by examining selected physicochemical and microbiological parameters and comparing them with relevant drinking water quality and effluent discharge standards.

\subsection{Materials and Methods}

\subsection{Study Area}

Aba Waterside (Aba) river is a deep freshwater river that passes through Ogbor hill area, Aba, Abia State, Nigeria (Figure 1). The river which is a tributary of Imo river is located between Latitude $5^{\circ}$ $05 \mathrm{~N}$ to $5^{\circ} 30 \mathrm{~N}$ and Longitude $7^{\circ} 15 \mathrm{E}$ to $7^{\circ} 40 \mathrm{E}$ is recharged by rainfall and groundwater (Amadi, 2012). It is a major source of water employed for domestic, agricultural and industrial purposes. The river continuously receives effluents and solid wastes from several industries, breweries, abattoirs, auto mechanic workshops and laundry services sited along its course. Domestic activities such as car washing, rearing of farm animals take place close to the river. There is also a refuse dumpsite located near the river (Atasie and Egbonu, 2017).

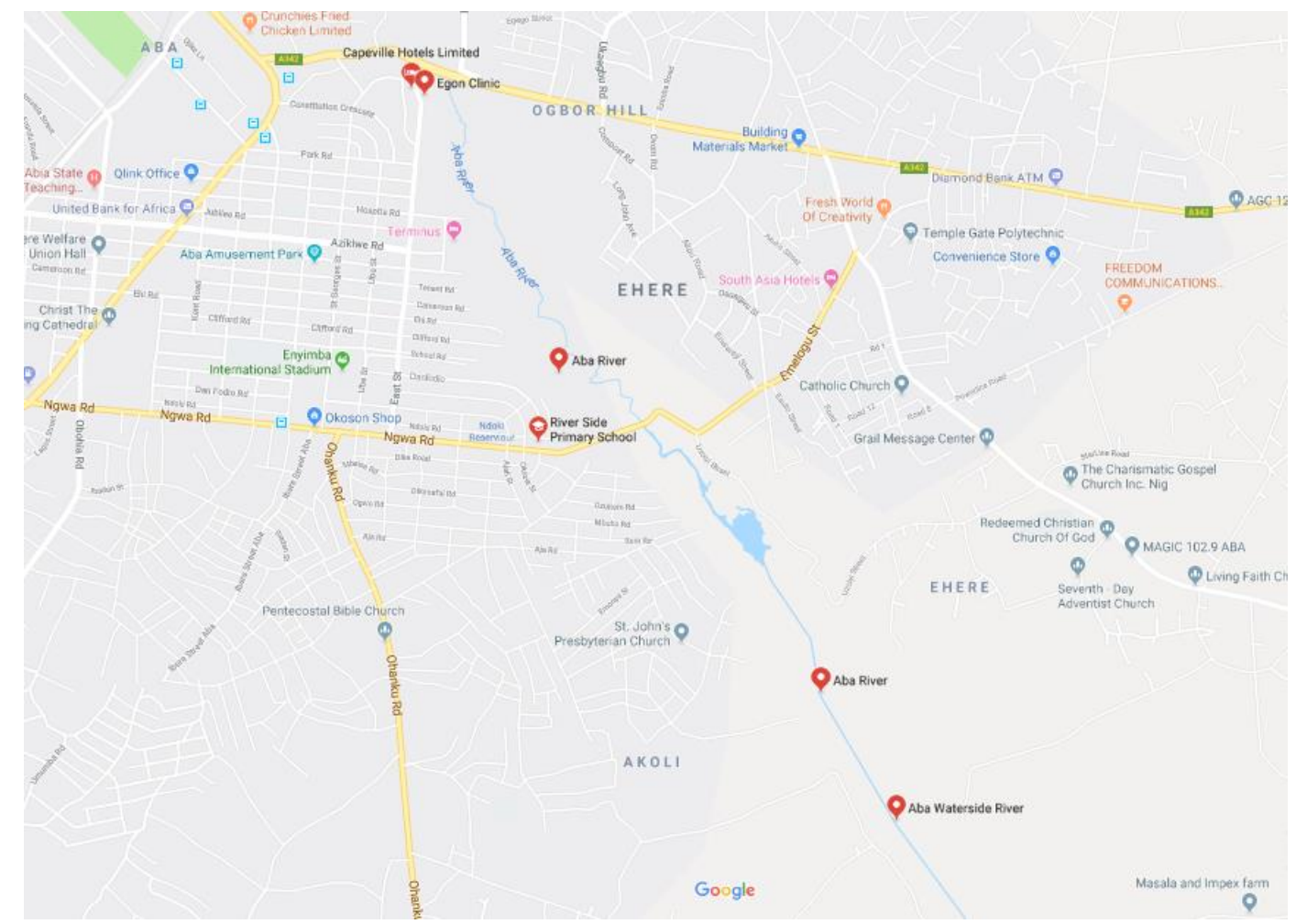

Figure 1: Map of the study area showing Aba Waterside River (Google maps, 2019) 


\subsection{Surface Water Sampling and Analysis}

Water samples were collected using thoroughly pre-rinsed $75 \mathrm{cl}$ plastic bottles with screw caps. Grab sampling was done upstream (the discharge point of a cosmetics factory), midstream (the discharge point of the abattoir under the Ogbor hill bridge) and downstream. The samples were then transported in a cooler packed with ice to Yemac consulting and analytical services limited, Aba for analysis.

The physicochemical parameters analyzed in accordance with standard methods for analysis of water and wastewater (APHA, 2012) include temperature, electrical conductivity, turbidity, $\mathrm{pH}$, total suspended solids (TSS), total dissolved solids (TDS), biochemical oxygen demand (BOD), chemical oxygen demand (COD), total hardness, iron, manganese, lead and zinc. The $\mathrm{pH}$ was determined using a calibrated $\mathrm{pH}$ meter and the temperature was determined using a thermometer. The DO was determined using Winkler's method (APHA, 2012). The determination of DO was done by adding manganese (II) sulfate to the water sample, followed by potassium hydroxide in a glass stoppered bottle, resulting in the oxidation of manganese and the formation of a brown precipitate. The solution was then acidified with sulfuric acid and alkaline iodide-azide reagent was added and the iodide was converted to iodine. The iodine was then titrated with a standard sodium thiosulfate $\left(\mathrm{Na}_{2} \mathrm{~S}_{2} \mathrm{O}_{3}\right)$ solution. The DO was then determined in direct proportion to the amount of thiosulfate required to reach the endpoint, using the stoichiometric relationship

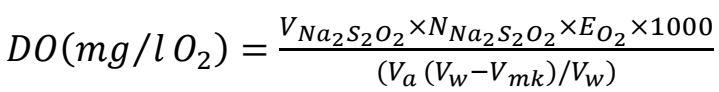

Where $\mathrm{Na}_{2} \mathrm{~S}_{2} \mathrm{O}_{2}$ is the volume of sodium thiosulfate used in titration $(\mathrm{ml}), \mathrm{N}_{\mathrm{Na}_{2} \mathrm{~S}_{2} \mathrm{O}_{2}}$ is the normality of sodium thiosulfate solution, $E_{\mathrm{O}_{2}}$ is the equivalent weight of oxygen, $V_{a}$ is the volume of analyte taken in solution (ml), $V_{m k}$ is the volume of manganese (II) sulfate and alkaline iodide reagent added $(\mathrm{ml})$ and $V_{w}$ is the total volume of the water sample (ml).

The BOD was determined by measuring the difference in the DO concentration of the samples before and after incubation at $20^{\circ} \mathrm{C}$ for five days using the equation:

$B O D_{5}=\frac{D O_{1}-D O_{2}}{p}$

Where $\mathrm{DO}_{1}$ and $\mathrm{DO}_{2}$ are the initial DO concentration of the sample before incubation and the DO concentration after 5 -day incubation at $20^{\circ} \mathrm{C}$ respectively $(\mathrm{mg} / \mathrm{l}) . P$ is the fraction of water sample to the total combined volume.

The COD was determined by refluxing the sample with a known excess of potassium dichromate in a high strength sulfuric acid solution. The excess potassium dichromate after digestion was titrated with ferrous ammonium sulfate to determine the amount consumed and the oxidizable matter (COD) was then calculated using Equation (3) (APHA, 2012).

$\operatorname{COD}\left(m g / l O_{2}\right)=\frac{8000(A-B) N}{V}$

Where A and B are the volume of ferrous ammonium sulfate used for the blank and the sample respectively ( $\mathrm{ml}), \mathrm{N}$ is the normality of ferrous ammonium sulfate and $\mathrm{V}$ is the volume of the water sample (ml).

The Conductivity, turbidity and TDS were measured directly using a Horiba U-10 water quality checker. Total hardness was determined by complexometric titration with a standard solution of ethylene diamine tetraacetic acid (EDTA), using erichrome as an indicator to a pure blue end point from pink. Elemental analysis was done using atomic absorption spectrophotometer (AAS). Enumeration of fecal coliforms was done using the most probable number (MPN) method (APHA, 2012; Ahmed et al., 2013). 


\subsection{Results and Discussion}

The result of physicochemical and microbiological analysis of the water samples is presented in Table 1. The results were compared with the Nigerian standard for drinking water quality (NIS-554-2015) (SON, 2015) and the national environmental effluent limitation regulations (FEPA, 1991). The comparison with drinking water quality standards was to assess the suitability of the water sources for direct potable use, as practiced by some inhabitants of the area.

The $\mathrm{pH}$ of water samples taken upstream (6.06) and midstream (6.58) did not exceed the maximum permissible limits for drinking water (SON, 2015) and discharge into surface water (FEPA, 1991). However, the water downstream was slightly acidic at $\mathrm{pH}$ 5.7. This is similar to observations in a different study area (Ewa et al., 2011) where pH was lower downstream than upstream. This may be due to high carbon dioxide emissions from increased organic matter decomposition rates resulting in the formation of a weak carbonic acid which decreases the $\mathrm{pH}$ of the water (Venkatesharaju et al., 2010). The temperatures ranging from $29-33^{\circ} \mathrm{C}$ were within acceptable limits for effluent discharge. The conductivity upstream was $1360 \mu / \mathrm{cm}$ which is higher than the maximum permitted value in drinking water. The conductivity is a measure of the capacity of water to conduct electrical current and is directly related to the amount of mineral salts dissolved in the water/ high TDS (Onojake et al., 2017). Liquid wastes from cosmetic industries such as soap factories located upstream are often characterized by heavy mineral loads (Ehouman et al, 2017). The TDS upstream (826mg/l) was higher than the maximum permissible limit for drinking water, and the midstream value $(2500 \mathrm{mg} / \mathrm{l})$ was higher than the maximum permissible limits for drinking water and effluent discharge. The TDS is a strong indicator of organic waste discharge into the river (Onojake et al, 2017).

Table 1: Water quality characteristics of samples obtained from Aba Waterside river, Aba.

\begin{tabular}{|c|c|c|c|c|c|}
\hline Parameter & Upstream & Midstream & Downstream & $\begin{array}{l}\text { NIS-554-2015 } \\
\text { (SON, 2015) }\end{array}$ & $\begin{array}{l}\text { FEPA } \\
(1991)\end{array}$ \\
\hline $\mathrm{pH}$ & 6.06 & 6.58 & 5.7 & $6.5-8.5$ & $6-9$ \\
\hline Temperature $\left({ }^{\circ} \mathrm{C}\right)$ & 33 & 30.5 & 29 & & $<40$ \\
\hline Conductivity $(\mu / \mathrm{cm})$ & 1360 & 150 & 101 & 1000 & \\
\hline $\mathrm{TSS}(\mathrm{mg} / \mathrm{l})$ & 906 & 2100 & 140 & & 30 \\
\hline TDS (mg/l) & 826 & 2500 & 60 & 500 & 2000 \\
\hline Turbidity (NTU) & 27 & 31 & 10 & 5 & \\
\hline Total Hardness (mg/l) & 195 & 5 & 16 & $150\left(\right.$ as $\left.\mathrm{CaCO}_{3}\right)$ & \\
\hline $\mathrm{DO}(\mathrm{mg} / \mathrm{l})$ & 4.7 & 6.7 & 2.6 & & \\
\hline BOD $(\mathrm{mg} / \mathrm{l})$ & 40 & 1960 & $21 . t 4$ & & 30 \\
\hline $\mathrm{COD}(\mathrm{mg} / \mathrm{l})$ & 96 & 122 & 102 & & \\
\hline $\mathrm{Fe}(\mathrm{mg} / \mathrm{l})$ & 3 & 0.89 & 0.05 & 0.3 & 20 \\
\hline $\operatorname{Mn}(\mathrm{mg} / \mathrm{l})$ & 2.8 & 1.2 & 1.85 & 0.2 & 5 \\
\hline $\mathrm{Pb}(\mathrm{mg} / \mathrm{l})$ & 0.01 & 0.32 & 0.01 & 0.01 & $<1$ \\
\hline $\mathrm{Zn}(\mathrm{mg} / \mathrm{l})$ & 0.015 & 0.01 & 0.05 & 3 & $<1$ \\
\hline $\begin{array}{l}\text { Fecal Coliforms } \\
\text { (MPN/100ml) }\end{array}$ & 3 & 198 & 28 & 0 & 400 \\
\hline
\end{tabular}

The total hardness varied from 5-195mg/l, with the hardness upstream $(195 \mathrm{mg} / \mathrm{l})$ exceeding the maximum permissible limits for drinking water. There are no associated health impacts, however at levels greater than $200 \mathrm{mg} / \mathrm{l}$, hardness may cause scale deposition and result in high soap consumption. Levels less than $100 \mathrm{mg} / \mathrm{l}$ (as observed midstream and downstream) may lower the buffering capacity 
of the water and increase corrosivity (WHO, 2017). The TSS ranged from $140-2100.33 \mathrm{mg} / \mathrm{l}$ and exceeded the FEPA guideline values. The turbidity levels $(10-31 \mathrm{mg} / \mathrm{l})$ were higher than the maximum permissible limits for drinking water (SON, 2015). Turbidity is a measure of suspended matter which reduces water clarity. Higher turbidity levels are often associated with higher levels of disease-causing microorganisms and harmful organic and inorganic substances. Suspended / colloidal solids can protect microorganisms and hinder effective disinfection (SON, 2015; WHO, 2017).

The BOD values were $40 \mathrm{mg} / \mathrm{l}, 1960 \mathrm{mg} / \mathrm{l}$ and $21 \mathrm{mg} / \mathrm{l}$ upstream, midstream and downstream respectively. The BOD upstream and midstream were greater than effluent discharge limits (FEPA, 1991). The BOD midstream was remarkably high due to the effluent discharged from the abattoirs at that point. High BOD levels result in the depletion of oxygen which is detrimental to aquatic life. Furthermore, the low dissolved oxygen measurements $(2.6-4.7 \mathrm{mg} / \mathrm{l})$ were due to the presence of organic matter in the water which consumes dissolved oxygen, and photosynthesis of proliferating aquatic plants. The concentration of manganese $(1.2-2.8 \mathrm{mg} / \mathrm{l})$ exceeded the permissible limit for drinking water. The Mn values are greater than those reported in Amadi (2012), where Mn concentrations ranges from 0.050-0.508 mg/l. According to the WHO (2017), at levels exceeding $0.1 \mathrm{mg} / \mathrm{l}$ manganese will cause an undesirable taste and stains. The concentration of $\mathrm{Pb}$ midstream $(0.32 \mathrm{mg} / \mathrm{l})$ was more than the permissible limit for drinking water (SON, 2015). The $\mathrm{Pb}$ values obtained (0.01-0.32 mg/l) were greater than those reported in Amadi (2012), where Pb concentrations ranged from $0.001-0.015 \mathrm{mg} / \mathrm{l}$ for the same river. This implies the continuous deterioration of the river quality and highlights the need for regular monitoring and environmental control. $\mathrm{Pb}$ is carcinogenic and toxic to the nervous system and may affect mental development in infants (SON, 2017). The concentration of zinc $(0.01-0.05 \mathrm{mg} / \mathrm{l})$ was less than the maximum permissible limits for both drinking water and discharge into surface water, thus indicating that zinc was not a pollutant of concern at the time of this study. The concentration of Fe ranged from $0.05-3 \mathrm{mg} / \mathrm{l}$ and was higher than the stipulated maximum values for drinking water (SON, 2015) upstream and midstream. These values were similar to the range reported in other heavy metal studies in Aba river (Amadi, 2012). The fecal coliform counts (3-198MPN/100ml) were within the acceptable range for effluent discharge, however they were greater than the maximum limits for drinking water. The presence of fecal coliforms from human and animal waste indicates the presence of other potentially harmful microorganisms which cause gastrointestinal illnesses which may result in fatalities in vulnerable segments of the population such as children and the elderly (Cliver, 2000).

\subsection{Conclusions}

The impact of anthropogenic activities on some water quality parameters of Aba Waterside river, Aba has been investigated. Generally, the results of physicochemical analysis revealed that levels of turbidity, manganese and iron at all points, conductivity and BOD upstream, and $\mathrm{Pb}$ and BOD midstream exceeded the stipulated values in the Nigerian standard for drinking water quality and/or the national environmental effluent limitation regulations. The BOD midstream (1960mg/l) was remarkably high due to the effluent discharged from the abattoirs at that point. Fecal coliforms (3$198 \mathrm{MPN} / 100 \mathrm{ml}$ ) were detected in all samples, indicating the presence of other potentially harmful microorganisms. The findings of the study indicate that the water is polluted and unsuitable for use as a drinking water source without appropriate treatment. More importantly, there is the need for continuous environmental monitoring and control to ensure that industries desist from discharging untreated effluents into the river to prevent further deterioration of the water quality.

\section{References}

Ahmed, T., Baidya, S., Acharjee, M. and Rahman, T. (2013) Qualitative analysis of drinking water through the most probable number (MPN) method. Stamford Journal of Microbiology,3(1), pp.9-16 
Ahwange, B.A., Agbaji, E.B. and Gimba, E.C. (2012) Impact assessment of human activities and seasonal variations on River Benue, within Makurdi metropolis. International Journal of Science and Technoology, 2(5), pp.248-254

Amadi, A.N. (2012) Quality Assessment of Aba River using heavy metal pollution index. American Journal of Environmental Engineering, 2(1), pp.45-49

APHA (2012) Standard Methods for the Examination of Water and Waste Water, 22nd edition, American Public Health Association, Washington DC.

Atasie, O.C. and Egbonu, A.C. (2017) Quality assessment of Aba Waterside river, Ogbor hill, Aba 1: effect of three-point samples on some hematological parameters of wistar rats. International Journal of Hydrology, 1(3), pp.68-71

Ayandiran, T.A., Fawole, O.O. and Dahunsi, S.O. (2018) Water quality assessment of bitumen polluted Oluwa River, South Western Nigeria. Water Resources and Industry, 19, pp.13-24

Cliver, D.O. (2000) Emerging pathogens on the rise: How can waterborne illness be prevented? California Agriculture, 54(5), pp.78-79

Dahunsi, S.O., Ayandiran, T.A., Oranusi, U.S., and Owamah, H.I. (2014) Drinking water quality and public health of selected communities in South Western Nigeria. Water Quality Exposure and Health, 6, pp.143-153

Ehouman, J., Yapo, B., Eudes, Y., Gnagne, A. and Ziao, N. (2017) Physico-chemical characterization of industrial liquid discharges of soap factories in Abidjan, Cote D'Ivoire. Journal of Geoscience and Environment Protection, 5(8), pp. 198-210

Ewa, E.E., Iwara, A.I., Adeyemi, J.A., Eja, E.I., Ajake, A.O. and Otu, C.A. (2011) Impact of industrial activities on water quality in Omoku creek. Sacha Journal of Environmental Studies, 1(2), pp. $8-16$

FEPA (1991) National Environmental (Effluent Limitation) Regulations, Federal Environmental Protection Agency

Google Maps (2019) Aba WaterSide River [Online]. Available at: https://google.com/maps/place/WaterSide+River+Aba [Accessed: 5 June 2019]

Morrison, G. O., Fatoki, O.S and Ekberg, A. (2001) Assessment of the impact of point source pollution from the Keiskammahoek sewage treatment plant on the Keiskamma River. Water SA, 27, pp. $475-480$

Nkwocha, E.E. and Emeribe, A.C. (2005) Proliferation of unsanitary solid waste dumpsites in urban and sub-urban areas in Nigeria: need for the construction of regional sanitary landfills. Journal of Environmental Systems, 31(4), pp.315-331

Onajoke, M.C., Sikoki, F.D., Omokheyeke, O. and Akpiri, R.U. (2017) Surface water characteristics and trace metals level of the Bonny/New Calabar River Estuary, Niger Delta, Nigeria. Applied Water Science, 7, pp.951-959

SON (2015) Nigerian standards for drinking water quality (NIS-554-2015), Standards Organization of Nigeria, Abuja

Tchakonte, S., Ajeagah, G., Diomande, D., Camara, A., Konan, K. and Ngassam, P. (2014) Impact of anthropogenic activities on water quality and freshwater shrimps diversity and distribution in five rivers in Douala, Cameroon. Journal of Biodiversity and Environmental Sciences, 4(2), pp.2222-3045

Tyagi S., Sharma, B., Singh, P. and Dobhal, R. (2013) Water quality assessment in terms of water quality index. American Journal of Water Resources, 1(3), pp.34-38 
Ubalua, A.O., Chijioke, U.C. and Ezeronye, O.U. (2007) Determination and assessment of heavy metal content in fish and shellfish in Aba River, Abia State, Nigeria. KMITL Science and Technology Journal, 7(1), pp.16-23

Udo, S.N. and Elendu, H. (2019) Public health implications of Aba river pollution on communitie in Aba North, Abia State, Nigeria. Texila International Journal of Public Health, 7(1), pp.1-8

Venkatesharaju, K., Ravikumar, P., Somashekar, R.K. and Prakash, K.L. (2010) Physico-chemical and bacteriological investigation on the river Cauvery of Kollegal stretch in Karnataka. Kathmandu University Journal of Science, Engineering and Technology, 6(1), pp.50-59

WHO (2017) Guidelines for drinking-water quality: fourth edition incorporating the first addendum, World Health Organization, Geneva. 